\title{
Effect of a gall-inducing psylloid, Pseudophacopteron alstonium Yang et Li (Hemiptera: Phacopteronidae) on defensive chemistry of Alstonia scholaris (L.) R. Br. (Gentianales: Apocynaceae)
}

\author{
Gal yapan bir psylloid Pseudophacopteron alstonium Yang et Li (Hemiptera: \\ Phacopteronidae)'un, Alstonia scholaris (L.) R. Br. (Gentianales: Apocynaceae)'in \\ kimyasal savunma yapısı üzerine etkisi
Zhen-De YANG ${ }^{1}$ Wen-Ling LV ${ }^{1} \quad$ Xia-Lin ZHENG ${ }^{2^{*}}$
Shu-Zhong YU ${ }^{1}$
Ming $\mathrm{LI}^{1}$

\section{Summary} \\ Gall-inducing insect species are capable to escape from defence of host plant species. However, effect of gall- \\ inducing insects on defensive mechanism of host plants is still unclear. The present study was conducted to evaluate \\ the possible chemical changes in the defensive system of Alstonia scholaris (L.) R. Br. (Gentianales: Apocynaceae) \\ caused by Pseudophacopteron alstonium Yang et Li (Hemiptera: Phacopteronidae) feeding. Total phenolic and \\ tannin, peroxidase, superoxide dismutase, catalase and polyphenol oxidase of gall (G) and non-galled (NG) tissues in \\ one leaf, whole leaf with gall (WG) from $1^{\text {st }}$ to $5^{\text {th }}$ stages induced by $P$. alstonium, and un-galled leaves (UL) were \\ measured in laboratory. High levels of secondary metabolites (i.e., total phenolic and tannin) and protective enzymes \\ were detected, which increased sharply during $1^{\text {st }}$ to $3^{\text {rd }}$ stages of galls and subsequently decreased when nymph \\ stoped feeding or entered into mature $\left(4^{\text {th }}\right.$ or $\left.5^{\text {th }}\right)$ stages. The recorded high levels of secondary metabolites and \\ protective enzymes in $A$. scholaris could be result of defensive response against $P$. alstonium. The current findings \\ could be helpful for understanding the interaction between plants and gall-formed insects.
}

Keywords: Pseudophacopteron alstonium; Alstonia scholaris; gall-inducing insect; defensive response

\section{Özet}

Gal yapan böcekler konukçu bitkilerin savunma mekanizmalarından kaçabilme yeteneklerine sahiptirler. Bununla birlikte gal yapan böceklerin bitkilerin savunma mekanizmalarına etkileri hala tam olarak bilinmemektedir. Bu çalışma Pseudophacopteron alstonium Yang et Li (Hemiptera: Phacopteronidae)'nin Alstonia scholaris (L.) R. Br. (Gentianales: Apocynaceae) üzerinde beslenmesi ile bitki savunma sisteminde meydana gelen kimyasal değişimleri belirlemek için yapılmıştır. P. alstonium tarafından birden beşinci seviyeye kadar uyarılmış Gall, aynı yaprakta galsiz yaprak parçası, ve hiç galsiz yapraktaki toplam tannin, peroksidaz, superoksid, dismutaz, katalaz ve polyphenol oksidaz düzeyleri laboratuvar koşullarında ölçülmüştür. Galin birinci evresinden üçüncü evresine kadar bitkide ikincil metabolitlerin (toplam phenolic ve tanin gibi) ve koruyucu enzimlerinde önemli bir artış tespit edilmişken, nimflerin beslenmeyi durdurduğu yada ergin hale geçtiği galin dördüncü ve beşinci evresinde bu değerler belirgin şekilde düşük bulunmuştur. $A$. scholaris'in ikincil metabolitlerinin ve koruyucu enzimlerinde meydana gelen bu artışın bitkinin $P$. alstonium'un beslenmesine verdiği tepkiden kaynaklandığı düşünülmektedir. Elde edilen bu bilgilerin bitki ve bitkilerde gallere neden olan böcekler arasındaki ilişkinin belirlenmesine yardımcı olacaktır.

Anahtar sözcükler: Pseudophacopteron alstonium; Alstonia scholaris; gal yapan böcek; savunma tepkisi

\footnotetext{
${ }^{1}$ College of Forestry, Guangxi University, Nanning, China

${ }^{2}$ College of Agriculture, Guangxi University, Nanning, China

* Sorumlu yazar (Corresponding author) e-mail: zheng-xia-lin@163.com

Alınış (Received): 06.03.2015 Kabul ediliş (Accepted): 30.12.2015
}

Çevrimiçi Yayın Tarihi (Published Online): 08.01.2016 


\section{Introduction}

Numerous microorganisms and arthropods interact intimately with plants and induce specialized structures - named as gall. The galling habit is especially common in more than 13,000 known gallforming insects species (Raman et al., 2005; Raman, 2012). Gall-inducing habit has evolved independently and multiple times in insects, resulting co-evolution between the plants and the gall-inducing insects leading to evolved strategies to avoid each other's defense systems (Raman et al., 2005).

Alstonia scholaris (L.) R. Br. (Gentianales: Apocynaceae) has been widely used for landscaping projects in Southeast Asia (including some southern provinces in China), Australia and United States (Kaushik et al., 2011). During recent years, this plant was seriously damaged by Pseudophacopteron alstonium Yang et Li (Hemiptera: Phacopteronidae) through gall-inducing, which effects the ornamental value, normal growth and development of A. scholaris (Yang \& Li, 1983; Qin et al., 2010; Zhang et al., 2011; Lv, 2012). P. alstonium has seven generations per year in Nanning City, Guangxi Zhuang Autonomous Region, China. Generation overlapped was observed. Spatial distribution of this species was aggregation distribution under natural conditons (Lv, 2012). Development of gall represents an outgrowth which results due to the interaction between gall-inducing insect and host plant. The production material of gall can provide an optimal material to explore the interaction between gall-inducing insect and host plants (Stone \& Schönrogge, 2003). However, effect of gall-inducing psylloid on defensive mechanism of host plants is still unclear. Understanding this information is helpful for exploring the coevolution between gall-inducing insects and host plants.

The aim of present study was to examine the effect of $P$.alstonium on defensive chemistry of A.scholaris. Therefore, the contents of total phenolic, tanni, levels of peroxidase, superoxide dismutase, and catalase and polyphenol oxidase were tested in A.scholaris during the five developmental stages of P.alstonium.

\section{Materials and Methods}

\section{Plant materials}

The development stages of galls on $A$. scholaris induced by $P$. alstonium (from $1^{\text {st }}$ to $5^{\text {th }}$ ) were collected from Nanning City, China $\left(108^{\circ} 28^{\prime} \mathrm{E}, 2^{\circ} 84^{\prime} \mathrm{N}\right)$ during 2011 (Figure 1). Gall (G) and non-galled (NG) tissues from the infested leaves were detected using a scalpel and used as first two treatments. Whereas, whole infested leaves (WG) and un-galled leaves (UL) were used as third and fourth treatment, respectively. UL were synchronously collected from the same $A$. scholaris trees. The leaves form (G, NG and WG) having gall density $(\leq 5)$ were chosen to study the effect of gall density on the nutritional contents, components and secondary metabolites of $A$. scholaris. Insects in galls of the $G$ and WG treatments were flushed using a distilled-water jet (Rongyi Experiment Equipment Co. Ltd., Guangxi, China). About $30 \mathrm{~g}$ samples of each treatment were obtained from ten $A$. scholaris leaves. All samples were cut into $1 \mathrm{~mm}$ fragments and stored in liquid nitrogen prior to analysis.
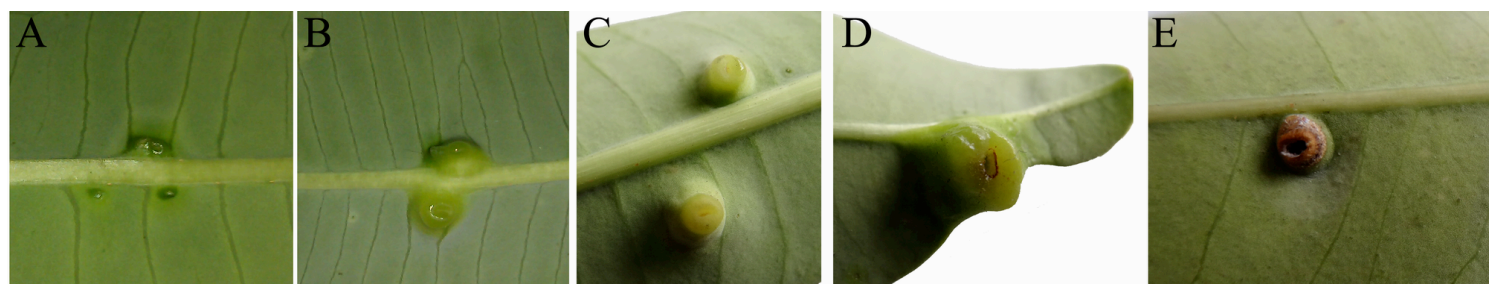

Figure 1. Galls from $1^{\text {st }}$ to $5^{\text {th }}$ developmental stages (A-E) induced by Pseudophacopteron alstonium on Alstonia scholaris. A. leaf attacked by $1^{\text {st }}$ instar larvae, and a protuberance appeared; B. ostiolate attacked by $P$. alstonium on galls was closed, a green gall formed; C. gall bulged and color changed to aqua or buff, but the color of closed ostiolate showed the amaranth; D. Emergence holes appeared on galls; E. Galls withered after emergence of $P$. alstonium adults. 


\section{Determination of total phenolic and tannin contents}

Total phenolic and tannin contents in the extracts were determined according to Ainsworth \& Gillespie (2007) and Makkar et al. (1993), respectively. Total $1.0 \mathrm{~g}$ samples of each treatment was soaked in $150 \mathrm{~mL}$ of $50 \%$ ethanol and acetone for $24 \mathrm{~h}$ and then filtered to obtain a filtrate. The ethanol and acetone extracts were obtained by evaporating filtrate at room temperature for 3 days. The evaporated extracts were cooled in a desiccator before further analysis. Fifty mg sample of each treatment were added into test tubes containing $2.5 \mathrm{~mL}$ of $10 \%(\mathrm{~V} / \mathrm{V})$ Folin-Ciocalteu reagent and $2.0 \mathrm{~mL}$ of sodium carbonate $(2 \%, W / V)$. After shaking, it was left for $2 \mathrm{~h}$ and the absorbance was measured at $750 \mathrm{~nm}$ using a spectrophotometer (GE Ultrospec 2100 pro, GE Healthcare, UK). Gallic acid was used as standard to obtain a calibration curve (ranging from 0 to $0.8 \mathrm{mg} / \mathrm{mL}^{-1}$ ). Using the standard curve, the content of total phenolic compounds was calculated and expressed as gallic acid equivalent in milligram per gram $(\mathrm{mg} / \mathrm{g})$ of dried extract. As for the level of total tannin, $50 \mathrm{mg}$ of the sample extract was added with $7.5 \mathrm{~mL}$ of distilled water and $0.5 \mathrm{~mL}$ of Folin-Ciocalteu reagent. Subsequently, $1 \mathrm{~mL}$ of $35 \%$ sodium carbonate solution and dilute to $10 \mathrm{~mL}$ with distilled water was added. Samples were kept at room temperature for $30 \mathrm{~min}$ after shaking and the absorbance was read at $725 \mathrm{~nm}$ using a spectrophotometer. Blank was established using distilled water instead of the samples. A set of standard solutions of gallic acid was dealt with in the same manner as described above and read against a blank. The results of tannins were expressed in terms of $\mathrm{mg}$ gallic acid/g of extract. Sample of each treatment was measured three times.

\section{Assays of peroxidase, superoxide dismutase, catalase and polyphenol oxidase activities}

Peroxidase activity was assayed spectrophotometrically with o-dianisidine as hydrogen donor (Sadasivam \& Manickam, 1996). A $3.5 \mathrm{~mL}$ of phosphate buffer $\left(0.2 \mathrm{~mol} / \mathrm{L} \mathrm{NaH}_{2} \mathrm{PO}_{4}\right.$ and $0.2 \mathrm{~mol} / \mathrm{L}$ $\mathrm{Na}_{2} \mathrm{HPO}_{4}, \mathrm{pH} 6.5$ ) was made in a clean dry cuvette, and $0.2 \mathrm{~mL}$ of plant extract and $0.1 \mathrm{~mL}$ of freshly prepared o-dianisidine solution was added. The temperature was maintained from $28^{\circ} \mathrm{C}$ to $30^{\circ} \mathrm{C}$ and the cuvette was placed in the spectrophotometer set at $430 \mathrm{~nm}$. Then, $0.2 \mathrm{~mL}$ of $0.2 \mathrm{M} \mathrm{H}_{2} \mathrm{O}_{2}$ was added and mixed in solution. Initial absorbance was read at every $30 \mathrm{sec}$ intervals up to $3 \mathrm{~min}$. A graph was plotted with the increase in absorbance against time. From the linear phase, the change in absorbance per min was read. Water blank was used in the assay. Sample of each treatment was measured three times.

The assay of superoxide dismutase activity was carried out with the method of Beauchamp \& Fridowich (1971) based on the reduction of nitroblue tetrazolium (NBT) chloride. The reduction of NBT by superoxide radicals to blue coloured formazan was followed at $560 \mathrm{~nm}$. Washed pellets treated with ethanol and chloroform was centrifuged after $15 \mathrm{~min}$ at $4{ }^{\circ} \mathrm{C}$ and supernatant was used for the assay. The reaction mixture contained, $1.9 \mathrm{~mL}$ of phosphate buffer $(\mathrm{pH} 7.8), 1 \times 10^{-2} \mathrm{M}$ methionine, $6.8 \times 10^{-5} \mathrm{M}$ NBT and $1.17 \times 10^{-6} \mathrm{M}$ riboflavin, with suitably diluted supernatant in a total volume of $3 \mathrm{~mL}$. Illumination of the solution taken in a $10 \mathrm{~mL}$ beaker was carried out in an aluminium foil lined box with a $15 \mathrm{~W}$ fluorescent lamp for $10 \mathrm{~min}$. Control without the enzyme source was always included. The absorbance was measured at $560 \mathrm{~nm}$ using a spectrophotometer. Sample of each treatment was measured three times.

Catalase activity was assayed with the titrimetric method described by Radhakissnan \& Sarma (1963). Briefly, $2.5 \mathrm{~mL}$ of $0.1 \mathrm{M}$ phosphate buffer, $\mathrm{pH} 7.5$ and $2.5 \mathrm{~mL}$ of $0.9 \%$ hydrogen peroxide $(\mathrm{v} / \mathrm{v})$ in the same buffer were taken and $0.5 \mathrm{~mL}$ of the plant extract was added and incubated at room temperature for $3 \mathrm{~min}$. The reaction was then stopped by adding $0.5 \mathrm{~mL}$ of $2 \mathrm{~N}$ sulphuric acids and the residual hydrogen peroxide was titrated with $0.1 \mathrm{~N}$ potassium permanganate solutions. Using similar arrangement, a blank was carried out with boiled enzyme extract. Sample of each treatment was measured three times. 
The polyphenol oxidase extraction procedure was described by Ortega-García et al. (2008). In order to establish the extracts of samples from each treatment, frozen samples in liquid nitrogen were pulverized using a pestle and mortar. Powder was homogenized in cold acetone $\left(-20{ }^{\circ} \mathrm{C}\right)$ and polyethyleneglycol (1W: 4V: $1 \mathrm{~V})$, and the homogenate refrigerated on dry ice. The solid fraction of the homogenate was separated by vacuum filtration and re-extracted again. The combined acetone extracts were dried overnight. Acetone powder was resuspended in $0.1 \mathrm{M}$ sodium phosphate buffer (1W: $30 \mathrm{~V}), \mathrm{pH}$ 6.8 with $0.3 \mathrm{mg} \mathrm{mL}^{-1}$ of type-II trypsin inhibitor, by gently stirring at $4{ }^{\circ} \mathrm{C}$ for $30 \mathrm{~min}$ before each polyphenol oxidase assay. The sample was filtered through glass wool and the filtrate centrifuged at $10000 \times \mathrm{g}$ for $20 \mathrm{~min}$ at $4{ }^{\circ} \mathrm{C}$. The absorbance was recorded at $475 \mathrm{~nm}$ using a spectrophotometer. Sample of each treatment was measured three times.

\section{Statistical analysis}

The statistical analysis was performed with SPSS 16.0 (SPSS Inc., Chicago, Illinois, USA). Means were compared using a one-way analysis of variance (ANOVA) followed by a Duncan's test $(P<0.05)$.

\section{Results}

\section{Variations of total phenolic and tannin contents}

Total phenolic content in G was significantly lower than NG, WG and UL treatments ( $F=51.186$; df $=3,11 ; P<0.001)$ at the first stage. However, this result was completely reversed from $2^{\text {nd }}$ to $5^{\text {th }}$ stages. Furthermore, total phenolic contents in $G$ and WG increased from $1^{\text {st }}$ to $4^{\text {th }}$ stages and decreased in the $5^{\text {th }}$ stage $(G, F=497.578$; df $=4,14 ; P<0.001$; WG, $F=100.880 ; \mathrm{df}=4,14 ; P<0.001)$. Increasing tendencies of total phenolic contents of both NG and UL suspended at the $4^{\text {th }}$ stage (NG, $F=430.933$; df $=4,14 ; P<0.001 ; \mathrm{UL}, F=257.694 ; \mathrm{df}=4,14 ; P<0.001$, Table 1).

Table 1. Total phenolic contents $(\mathrm{mg} / \mathrm{g})$ of $U L$ in comparison with $\mathrm{NG}$, WG and $\mathrm{G}$ tissues induced by Pseudophacopteron alstonium on Alstonia scholaris

\begin{tabular}{cccccc}
\hline \multirow{2}{*}{ Treatments } & \multicolumn{5}{c}{ Developmental duration of galls } \\
\cline { 2 - 6 } & I & II & III & IV & V \\
\hline UL & $21.64 \pm 0.43 \mathrm{cE}$ & $24.56 \pm 0.34 \mathrm{bC}$ & $35.23 \pm 0.52 \mathrm{cA}$ & $33.86 \pm 0.56 \mathrm{~dB}$ & $23.25 \pm 0.15 \mathrm{dD}$ \\
NG & $24.56 \pm 0.60 \mathrm{aD}$ & $30.01 \pm 0.99 \mathrm{aBC}$ & $39.37 \pm 0.57 \mathrm{bA}$ & $30.70 \pm 0.85 \mathrm{cB}$ & $27.81 \pm 0.77 \mathrm{cC}$ \\
WG & $23.42 \pm 0.43 \mathrm{bC}$ & $29.70 \pm 0.46 \mathrm{aB}$ & $44.82 \pm 1.89 \mathrm{aA}$ & $45.19 \pm 0.42 \mathrm{bA}$ & $31.15 \pm 0.13 \mathrm{bB}$ \\
G & $19.88 \pm 0.60 \mathrm{dE}$ & $28.82 \pm 0.26 \mathrm{aD}$ & $48.48 \pm 0.78 \mathrm{aB}$ & $50.47 \pm 0.64 \mathrm{aA}$ & $40.13 \pm 0.14 \mathrm{aC}$
\end{tabular}

Different lowercase letters at the same row and capital letters at the same column indicate statistical significance at $P<0.05$. UL, un-galled leaves; NG, non-galled tissue on a leaf with galls induced by $P$. alstonium; WG, whole leaf with gall; $G$, only gall on a leaf with galls induced by $P$. alstonium.

Total tannin content in G was lower than UL, NG and WG at the $1^{\text {st }}$ stage $(F=0.385 ; \mathrm{df}=3,11 ; P$ $=0.767)$. From $2^{\text {nd }}$ to $5^{\text {th }}$ stages, total tannin contents in $\mathrm{G}$ were always higher than other treatments $\left(2^{\text {nd }}\right.$, $F=194.028 ; \mathrm{df}=3,11 ; P<0.001 ; 3^{\text {rd }}, F=367.635 ; \mathrm{df}=3,11 ; P<0.001 ; 4^{\text {th }}, F=373.365 ; \mathrm{df}=3,11 ; P<$ $0.001 ; 5^{\text {th }}, F=144.698 ; \mathrm{df}=3,11 ; P<0.001$, Table 2). Furthermore, the increasing tendency was found in the treatments of UL, NG and WG as the growth and development of galls (UL, $F=34.759$; df $=4,14$; $P<0.001$; NG, $F=58.38$; df $=4,14 ; P<0.001$; WG, $F=266.146 ; \mathrm{df}=4,14 ; P<0.001$ ). As for the treatment of $G$, increasing tendencies suspended at the $5^{\text {th }}$ stage $(G, F=355.704 ; \mathrm{df}=4,14 ; P<0.001)$. 
Table 2. Total tannin contents $(\mathrm{mg} / \mathrm{g}$ ) of $\mathrm{UL}$ in comparison with $\mathrm{NG}$, WG and $\mathrm{G}$ tissues induced by Pseudophacopteron alstonium on Alstonia scholaris

\begin{tabular}{cccccc}
\hline \multirow{2}{*}{ Treatments } & \multicolumn{5}{c}{ Developmental duration of galls } \\
\cline { 2 - 6 } & I & II & III & IV & V \\
\hline UL & $10.03 \pm 0.60 \mathrm{aC}$ & $13.27 \pm 0.44 \mathrm{bB}$ & $13.79 \pm 1.00 \mathrm{~dB}$ & $14.83 \pm 0.75 \mathrm{~dB}$ & $22.04 \pm 0.84 \mathrm{cA}$ \\
NG & $10.35 \pm 0.50 \mathrm{aD}$ & $13.19 \pm 0.44 \mathrm{bC}$ & $18.79 \pm 0.45 \mathrm{cB}$ & $18.65 \pm 0.70 \mathrm{cB}$ & $21.64 \pm 0.83 \mathrm{cA}$ \\
WG & $10.83 \pm 0.66 \mathrm{aC}$ & $12.44 \pm 0.36 \mathrm{bC}$ & $34.52 \pm 0.71 \mathrm{bB}$ & $32.89 \pm 0.94 \mathrm{bB}$ & $40.25 \pm 1.81 \mathrm{bA}$ \\
G & $9.95 \pm 0.77 \mathrm{aE}$ & $25.22 \pm 0.51 \mathrm{aD}$ & $52.22 \pm 1.23 \mathrm{aB}$ & $58.24 \pm 1.48 \mathrm{aA}$ & $44.16 \pm 0.88 \mathrm{aC}$
\end{tabular}

Different lowercase letters at the same row and capital letters at the same column indicate statistical significance at $P<0.05$. UL, un-galled leaves; NG, non-galled tissue on a leaf with galls induced by $P$. alstonium; WG, whole leaf with gall; $G$, only gall on a leaf with galls induced by $P$. alstonium.

\section{Variations of peroxidase, superoxide dismutase, catalase and polyphenol oxidase contents}

Peroxidase activities in $G$ were higher than NG, WG and UL treatments from $1^{\text {st }}$ to $3^{\text {rd }}$ stages $\left(1^{\text {st }}, F\right.$ $=493.252 ; \mathrm{df}=3,11 ; P<0.001 ; 2^{\text {nd }}, F=1044.000 ; \mathrm{df}=3,11 ; P<0.001 ; 3^{\text {rd }}, F=164.921 ; \mathrm{df}=3,11 ; P<$ 0.001 ). Furthermore, peroxidase activities ascended in the first two stages and subsequently descended in the four treatments were found (UL, $F=245.421$; df $=4,14 ; P<0.001$; NG, $F=453.697$; df $=4,14 ; P<$ 0.001; WG, $F=617.173 ; \mathrm{df}=4,14 ; P<0.001 ; \mathrm{G}, F=2856.000 ; \mathrm{df}=4,14 ; P<0.001$, Table 3).

Table 3. Peroxidase contents $(\mu \mathrm{g} /(\mathrm{g} \cdot \mathrm{min}))$ of $\mathrm{UL}$ in comparison with NG, WG and $\mathrm{G}$ tissues induced by Pseudophacopteron alstonium on Alstonia scholaris

\begin{tabular}{cccccc}
\hline \multirow{2}{*}{ Treatments } & \multicolumn{5}{c}{ Developmental duration of galls } \\
\cline { 2 - 6 } & I & II & III & IV & V \\
\hline UL & $234.24 \pm 2.09 \mathrm{dA}$ & $232.44 \pm 6.30 \mathrm{dA}$ & $144.94 \pm 4.64 \mathrm{cB}$ & $115.95 \pm 3.66 \mathrm{aC}$ & $102.38 \pm 1.68 \mathrm{aD}$ \\
NG & $270.96 \pm 3.51 \mathrm{cB}$ & $299.38 \pm 4.07 \mathrm{cA}$ & $165.40 \pm 5.69 \mathrm{cC}$ & $111.13 \pm 3.77 \mathrm{aD}$ & $97.80 \pm 4.22 \mathrm{aD}$ \\
WG & $369.24 \pm 4.35 \mathrm{bB}$ & $460.20 \pm 3.82 \mathrm{bA}$ & $256.73 \pm 12.94 \mathrm{bC}$ & $89.27 \pm 3.60 \mathrm{bD}$ & $99.56 \pm 1.58 \mathrm{aD}$ \\
G & $408.93 \pm 4.33 \mathrm{aB}$ & $560.31 \pm 3.83 \mathrm{aA}$ & $362.71 \pm 4.35 \mathrm{aC}$ & $105.73 \pm 3.81 \mathrm{aD}$ & $93.75 \pm 2.19 \mathrm{aE}$ \\
\hline
\end{tabular}

Different lowercase letters at the same row and capital letters at the same column indicate statistical significance at $P<0.05$. UL, un-galled leaves; NG, non-galled tissue on a leaf with galls induced by $P$. alstonium; WG, whole leaf with gall; $G$, only gall on a leaf with galls induced by $P$. alstonium.

Superoxide dismutase activities in $G$ at the first stage were significantly higher than NG, WG and UL treatments $(F=21.586$; $d f=3,11 ; P<0.001)$. However, its activities in $\mathrm{G}$ was lower than $N G$ at the $3^{\text {rd }}$ stage $(F=150.068 ; \mathrm{df}=3,11 ; P<0.001), \mathrm{NG}, \mathrm{WG}$ and $\mathrm{UL}$ at the $4^{\text {th }}$ stage $(F=28.034 ; \mathrm{df}=3,11 ; P<$ $0.001)$, and NG and $\mathrm{UL}$ at the $5^{\text {th }}$ stage $(F=61.795 ; \mathrm{df}=3,11 ; P<0.001)$. As for the dynamic variations of the four treatments, there was no visible tendency in NG, WG and UL treatments, except for $G$ in which superoxide dismutase activities increased from $1^{\text {st }}$ to $3^{\text {rd }}$ stages and suspended at the $4^{\text {th }}$ stage $(F=$ 99.06; $\mathrm{df}=4,14 ; P<0.001$, Table 4).

From $1^{\text {st }}$ to $4^{\text {th }}$ stages, catalase activities in $\mathrm{G}$ were higher than other treatments all the time $\left(1^{\text {st }}, F\right.$ $=18.629 ; \mathrm{df}=3,11 ; P<0.01 ; 2^{\text {nd }}, F=76.314 ; \mathrm{df}=3,11 ; P<0.001 ; 3^{\text {rd }}, F=35.975 ; \mathrm{df}=3,11 ; P<0.001$; $4^{\text {th }}, F=44.124 ; \mathrm{df}=3,11 ; P<0.001$, Table 5$)$. However, its activity was significantly lower than NG, WG and UL treatments at the $5^{\text {th }}$ stage $(F=194.357 ; \mathrm{df}=3,11 ; P<0.001)$. Dynamic variations of the four treatments were inconspicuous. 
Effect of a gall-inducing psylloid, Pseudophacopteron alstonium Yang et Li (Hemiptera: Phacopteronidae) on defensive chemistry of Alstonia scholaris (L.) R. Br. (Gentianales: Apocynaceae)

Table 4. Superoxide dismutase contents $(\mathrm{U} /(\mathrm{g} \cdot \mathrm{min}))$ of $\mathrm{UL}$ in comparison with NG, WG and $\mathrm{G}$ tissues induced by Pseudophacopteron alstonium on Alstonia scholaris

\begin{tabular}{cccccc}
\hline \multirow{2}{*}{ Treatments } & \multicolumn{5}{c}{ Developmental duration of galls } \\
\cline { 2 - 6 } & $\mathrm{I}$ & $\mathrm{II}$ & $\mathrm{III}$ & $\mathrm{IV}$ & $\mathrm{V}$ \\
\hline UL & $195.50 \pm 1.74 \mathrm{cD}$ & $433.02 \pm 6.29 \mathrm{cB}$ & $351.92 \pm 4.18 \mathrm{cC}$ & $448.42 \pm 4.95 \mathrm{bA}$ & $355.79 \pm 1.11 \mathrm{aC}$ \\
NG & $221.94 \pm 5.14 \mathrm{bD}$ & $470.46 \pm 4.01 \mathrm{abB}$ & $499.23 \pm 7.81 \mathrm{aA}$ & $512.05 \pm 3.11 \mathrm{aA}$ & $336.53 \pm 5.94 \mathrm{bC}$ \\
WG & $207.54 \pm 5.83 \mathrm{cE}$ & $454.32 \pm 6.03 \mathrm{bA}$ & $339.08 \pm 8.00 \mathrm{cC}$ & $408.88 \pm 7.32 \mathrm{cB}$ & $288.94 \pm 5.48 \mathrm{cD}$ \\
G & $241.94 \pm 3.25 \mathrm{aE}$ & $480.78 \pm 8.71 \mathrm{aA}$ & $434.98 \pm 2.82 \mathrm{bB}$ & $377.44 \pm 19.81 \mathrm{cC}$ & $291.60 \pm 2.23 \mathrm{cD}$ \\
\hline
\end{tabular}

Different lowercase letters at the same row and capital letters at the same column indicate statistical significance at $P<0.05$. UL, un-galled leaves; NG, non-galled tissue on a leaf with galls induced by $P$. alstonium; WG, whole leaf with gall; G, only gall on a leaf with galls induced by $P$. alstonium.

Table 5. Catalase contents $(\mathrm{U} /(\mathrm{g} \cdot \mathrm{min}))$ of $U L$ in comparison with $N G$, WG and $G$ tissues induced by Pseudophacopteron alstonium on Alstonia scholaris

\begin{tabular}{cccccc}
\hline \multirow{2}{*}{ Treatments } & \multicolumn{5}{c}{ Developmental duration of galls } \\
\cline { 2 - 6 } & I & II & III & IV & V \\
\hline UL & $22.35 \pm 0.64 \mathrm{cC}$ & $26.90 \pm 1.12 \mathrm{cB}$ & $25.40 \pm 0.25 \mathrm{cB}$ & $35.68 \pm 1.32 \mathrm{cA}$ & $34.05 \pm 0.91 \mathrm{bA}$ \\
NG & $24.22 \pm 1.02 \mathrm{cCD}$ & $26.13 \pm 0.93 \mathrm{cC}$ & $22.52 \pm 1.19 \mathrm{cD}$ & $46.19 \pm 0.42 \mathrm{bA}$ & $42.82 \pm 1.12 \mathrm{aB}$ \\
WG & $26.62 \pm 0.57 \mathrm{bC}$ & $33.40 \pm 0.23 \mathrm{bB}$ & $32.19 \pm 1.38 \mathrm{bB}$ & $45.89 \pm 1.92 \mathrm{bA}$ & $27.64 \pm 1.17 \mathrm{cC}$ \\
G & $29.64 \pm 0.59 \mathrm{aD}$ & $43.74 \pm 0.14 \mathrm{aB}$ & $36.01 \pm 0.91 \mathrm{aC}$ & $57.54 \pm 1.28 \mathrm{aA}$ & $11.77 \pm 0.28 \mathrm{dE}$ \\
\hline
\end{tabular}

Different lowercase letters at the same row and capital letters at the same column indicate statistical significance at $P<0.05$. UL, un-galled leaves; NG, non-galled tissue on a leaf with galls induced by $P$. alstonium; WG, whole leaf with gall; $G$, only gall on a leaf with galls induced by $P$. alstonium.

Polyphenol oxidase activities in $G$ were significantly higher than other three treatments at the $1^{\text {st }}$ stage $(F=8.26 ; \mathrm{df}=3,11 ; P<0.01)$, and NG and $U L$ treatments at the $4^{\text {th }}$ stage $(F=95.336 ; \mathrm{df}=3,11$; $P<0.001)$. However, polyphenol oxidase activity in $G$ at the $5^{\text {th }}$ stage was significantly lower than other three treatments $(F=24.815 ; \mathrm{df}=3,11 ; P<0.001)$. Polyphenol oxidase activities in $\mathrm{G}, \mathrm{NG}$ and WG were increased from $1^{\text {st }}$ to $4^{\text {th }}$ stages and suspended at $5^{\text {th }}$ stage except for UL (UL, $F=324.093 ; \mathrm{df}=4,14 ; P<$ 0.001 ; NG, $F=328.633$; df = 4, 14; $P<0.001$; WG, $F=105.887$; df = 4, 14; $P<0.001 ; G, F=101.076$; df $=4,14 ; P<0.001$, Table 6).

Table 6. Polyphenol oxidase contents $(\mathrm{U} /(\mathrm{g} \cdot \mathrm{min}))$ of $\mathrm{UL}$ in comparison with NG, WG and $\mathrm{G}$ tissues induced by Pseudophacopteron alstonium on Alstonia scholaris

\begin{tabular}{cccccc}
\hline \multirow{2}{*}{ Treatments } & \multicolumn{5}{c}{ Developmental duration of galls } \\
\cline { 2 - 6 } & I & II & III & IV & V \\
\hline UL & $9.96 \pm 0.11 \mathrm{bC}$ & $10.12 \pm 0.25 \mathrm{cC}$ & $20.49 \pm 0.59 \mathrm{cB}$ & $22.01 \pm 0.30 \mathrm{cA}$ & $22.97 \pm 0.38 \mathrm{bA}$ \\
NG & $9.88 \pm 0.07 \mathrm{bE}$ & $15.44 \pm 0.71 \mathrm{bD}$ & $24.69 \pm 0.71 \mathrm{bcC}$ & $35.42 \pm 0.64 \mathrm{bA}$ & $31.40 \pm 0.56 \mathrm{aB}$ \\
WG & $10.52 \pm 0.36 \mathrm{bD}$ & $17.96 \pm 0.47 \mathrm{aC}$ & $37.65 \pm 2.24 \mathrm{aA}$ & $41.52 \pm 1.40 \mathrm{aA}$ & $29.56 \pm 0.87 \mathrm{aB}$ \\
G & $11.52 \pm 0.35 \mathrm{aD}$ & $14.29 \pm 0.25 \mathrm{bCD}$ & $28.53 \pm 1.00 \mathrm{bB}$ & $41.39 \pm 1.04 \mathrm{aA}$ & $17.58 \pm 2.28 \mathrm{cC}$ \\
\hline
\end{tabular}

Different lowercase letters at the same row and capital letters at the same column indicate statistical significance at $P<0.05$. UL, un-galled leaves; NG, non-galled tissue on a leaf with galls induced by $P$. alstonium; WG, whole leaf with gall; $G$, only gall on a leaf with galls induced by $P$. alstonium. 


\section{Discussion}

Plants and insects have evolved strategies to avoid each other's defense systems. To counter the herbivore attack, plants produce specialized morphological structures (e.g., hairs, trichomes, thorns, spines and thicker leaves) (Howe \& Schaller, 2008) or secondary metabolites and proteins that have toxic, repellent, and/or antinutitional effects on the herbivores (Fürstenberg-Hägg et al., 2013) or trickery (Ellison \& Gotelli, 2001). In the current study, results illustrated that high levels of secondary metabolites (i.e., total phenolic and tannin) and protective enzymes in galls were detected. Furthermore, contents of secondary metabolites and protective enzymes of galls increased sharply from the $1^{\text {st }}$ to $3^{\text {rd }}$ stages of galls and subsequently decreased when nymph stops feeding or enters into a mature stage at the $4^{\text {th }}$ or $5^{\text {th }}$ stages of galls. We considered that these high levels of secondary metabolites and protective enzymes maybe were the defensive response when $A$. scholaris attacked by $P$. alstonium.

How plants defend themselves against attack from herbivores has been the subject of considerable interest over many decades. Production of toxic chemicals (e.g., terpenoids, alkaloids, anthocyanins, phenols and quinones) that either kill or retard the development of the herbivores (Hanley et al., 2007) and proteins that have toxic, repellent, and/or antinutitional effects on the herbivores (War et al., 2011) are the direct defenses mediated by plant characteristics. However, gall-formed insects have evolved ways to hijack plant defenses to their own benefit, by sequestering these chemicals and using them to protect themselves from predators, parasitoids, pathogens and other herbivores. This notion has been termed the enemy hypothesis (Price et al., 1987; Schultz, 1992; Hartley, 1998). Our findings showed that levels of secondary metabolites (i.e., total phenolic and tannin) in G were significantly greater than NG, WG and UL treatments, meanwhile the increasing tendencies suspended when nymph stopped feeding or entered into a mature stage. This result is consistent with previous conclusion studied on the galls induced by Slavum wertheimae H.R.L. (Hemiptera: Pemphigidae) on Pistacia atlantica Desf. (Sapindales: Anacardiaceae) (Rostás et al., 2013). Therefore, we speculated that high levels of gall secondary metabolites confer protection against natural enemies but such a trade-off needs to be investigated.

One of the crucial aspects of host plant resistance against herbivore is the disruption of insect's nutrition. The enzymes that impair the nutrient uptake by insects through the formation of electrophiles includes peroxidase, polyphenol oxidase, superoxide dismutase, etc. (War et al., 2012). In this study, data demonstrated that peroxidase, superoxide dismutase, catalase and polyphenol oxidase activities in $G$ was the highest and gradually enhanced from $1^{\text {st }}$ to $3^{\text {rd }}$ stages of galls (Tables 3-6). However, activities of these enzymes decreased when nymph stops feeding or enters into a mature stage at the $4^{\text {th }}$ or $5^{\text {th }}$ stages of galls (Tables 3-6). These results strongly suggest that higher levels of peroxidase, superoxide dismutase, catalase and polyphenol oxidase in $G$ were the defensive response when $A$. scholaris attacked by $P$. alstonium.

It can be hypothesized that a great deal of secondary metabolites and protective enzymes accumulated in galls when $A$. scholaris leaves damaged by nymph of $P$. alstonium. However, it is confused that how does nymph of $P$. alstonium adapt to the extreme conditions in galls (i.e., high levels of secondary metabolites and protective enzymes) needs to further study.

\section{Acknowledgements}

This work was supported by the National Natural Science Foundation of China under Grant (31160165, 31300549, 31560212), Guangxi Natural Science Foundation under Grant (2013GXNSFBA019111), Bossco Scholar Programme on Cultivation of Creative Talents from Young Teachers in Guangxi University, and Guangxi Special Invited Scientist Program in Agric-Environment and Agric-Products Safety (2013B015). 
Effect of a gall-inducing psylloid, Pseudophacopteron alstonium Yang et Li (Hemiptera: Phacopteronidae) on defensive chemistry of Alstonia scholaris (L.) R. Br. (Gentianales: Apocynaceae)

\section{References}

Ainsworth, E.A. \& K.M. Gillespie, 2007. Estimation of total phenolic content and other oxidation substrates in plant tissues using Folin-Ciocalteu reagent. Nature Protocols, 2: 875-877.

Beauchamp, C. \& I. Fridowich, 1971. Superoxide dismutase: improved assays and an assay applicable to acrylamide gels. Analytical Biochemistry, 44: 276-287.

Ellison, A.M. \& N.J. Gotelli, 2001. Evolutionary ecology of carnivorous plants. Trends in Ecology \& Evolution, 16: 623-629.

Fürstenberg-Hägg, J., M. Zagrobelny \& S. Bak, 2013. Plant defense against insect herbivores. International Journal of Molecular Sciences, 14: 10242-10297.

Hanley, M.E., B.B. Lamont, M.M. Fairbanks \& C.M. Rafferty, 2007. Plant structural traits and their role in antiherbivore defense. Perspectives in Plant Ecology Evolution and Systematics, 8: 157-178.

Hartley, S.E., 1998. The chemical composition of plant galls: are levels of nutrients and secondary compounds controlled by the gall former? Oecologia, 113: 492-501.

Howe, G.A. \& A. Schaller, 2008. "Direct Defenses in Plants and Their Induction by Wounding and Insect Herbivores. 7-29". In: Induced Plant Resistance to Herbivory (Ed: A. Schaller) Berlin, Germany: Springer-Verlag, 480 pp.

Kaushik, P., D. Kaushik, N. Sharma \& A.C. Rana, 2011. Alstonia scholaris: It's phytochemistry and pharmacology. Chronicles of Young Scientists, 2: 71-78.

Lv, W.L., 2012. Biological characteristics of Pseudophacopteron alstonium (Homoptera: Phacopteronidae) and its effect on physiological and biochemical indices of Alstonia scholaris (Gentianales: Apocynaceae). (Unpublished) Master thesis, Guangxi University, Nanning, China, 69 pp.

Makkar, H.P.S, M. Bluemmel, N.K. Borowy \& K. Becker, 1993. Gravimetric determination of tannins and their correlations with chemical and protein precipitation methods. Journal of the Science of Food and Agriculture, 61: 161-165.

Ortega-García, F., S. Blanco, M.A. Peinado \& J. Peragón, 2008. Polyphenol oxidase and its relationship with oleuropein concentration in fruits and leaves of olive (Olea europaea) cv. 'Picual' trees during fruit ripening. Tree Physiology, 28: 45-54.

Price, P.W., G.W. Fernandes \& G.L. Waring, 1987. Adaptive nature of insect galls. Environmental Entomology, 16: 15-24.

Qin, J.P., Z.Q. Zhang, Z.D. Yang, Y.W. Ju, W.Y. Zhang, W.L. Lv \& Y.H. Yu, 2010. Morphological and occurring characteristics of Pseudophacopteron alstonium. China Plant Protection, 30: 27-29.

Radhakissnan, T.M. \& P.S. Sarma, 1963. Intracellular localization and biosynthesis of catalase in liver tissues. Current Science, 32: 1749.

Raman, A., C.W. Schaefer \& T.M. Withers, 2005. Biology, ecology, and evolution of gall-induced arthropods (Vol. 1 \& 2). Hampshire, England: Science Publisher Ltd.

Raman, A., 2012. Gall induction by hemipteroid insects. Journal of Plant Interactions, 7: 29-44.

Rostás, M., D. Maag, M. Ikegami \& M. Inbar, 2013. Gall volatiles defend aphids against a browsing mammal. BMC Evolutionary Biology, 13: 193.

Sadasivam, S. \& A. Manickam, 1996. Methods in Biochemistry. New Age International Private Limited, New Delhi, India, 15 pp.

Schultz, B.B., 1992. Insect herbivores as potential causes of mortality and adaptation in gall forming insects. Oecologia, 90: 297-299.

Stone, G.N. \& K. Schönrogge, 2003. The adaptive significance of insect gall morphology. Trends in Ecology \& Evolution, 18: 512-514.

War, A.R., M.G. Paulraj, T. Ahmad, A.A. Buhroo, B. Hussain, S. Ignacimuthu \& H.C. Sharma, 2012. Mechanisms of plant defense against insect herbivores. Plant Signal Behavior, 7: 1306-1320.

War, A.R., M.G. Paulraj, M.Y. War \& S. Ignacimuthu, 2011. Herbivore- and elicitor-induced resistance in groundnut to Asian armyworm, Spodoptera litura Fab. (Lepidoptera: Noctuidae). Plant Signal Behavior, 6: 1769-1777.

Yang, C.K. \& F.S. Li, 1983. A preliminary study on Chinese Pseudophacopteron with descriptions of three new species (Homoptera: Psyllidae). Wuyi Science, 3: 120-128.

Zhang, W.Y., W.L. Lv, Z.D. Yang, Z.Q. Zhang \& S.M. Lei, 2011. Effect of Pseudophacopteron alstonium on photosynthetic parameters and chlorophyll content of Alstonia scholaris. China Plant Protection, 31: 7-10. 